\title{
The quality of the Treated effluent, Raw Influent and Wastewater-polluted Water sources Used for Irrigation of Vegetables in Urban and Peri-Urban Areas of Nairobi County, Kenya
}

\author{
David K. Rono ${ }^{1}$ and Joseph P. Gweyi-Onyango ${ }^{2}$
}

\begin{abstract}
${ }^{1}$ Masinde Muliro University of Science and Technology, Department of Disaster Management and Sustainable Development, P. O. Box 190-50100 Kakamega, Kenya

${ }^{2}$ Department of Agricultural Science and Technology, Kenyatta University, P. O. Box 43844-00100 Nairobi, Kenya
\end{abstract}

DOI: 10.29322/IJSRP.11.05.2021.p11333

http://dx.doi.org/10.29322/IJSRP.11.05.2021.p11333

\begin{abstract}
Nearly half of the wastewater generated in Nairobi ended up treated in the treatment facilities. However, cases of irrigating vegetables with raw influent and untreated wastewater water by urban and peri-urban farmers in Nairobi have been noted. Despite the importance of wastewater in in Kenya's urban and peri-urban agriculture, information on the quality of water used for irrigation areas is lacking. This study sought to establish physicochemical and microbiological composition of water used for irrigating vegetables in Ruai ward, Nairobi County, Kenya. A preliminary survey was conducted to identify sources of water used for irrigation. Sources of water used for irrigation were then categorized into the treated effluent, raw influent and wastewaterpolluted water sources. From these sources sampling points were randomly selected and georeferenced. Parameters investigated for physicochemical characteristics are total dissolved solids (TDS), aluminium $(\mathrm{Al})$, cadmium $(\mathrm{Cd})$, chromium $(\mathrm{Cr})$, cobalt $(\mathrm{Co})$, copper $(\mathrm{Cu})$, zinc $(\mathrm{Zn})$ and lead $(\mathrm{Pb})$. Microbiological organisms determined in the samples are total coliforms and Escherichia coli. Concentration of TDS was determined using evaporation method, while $\mathrm{Al}, \mathrm{Cd}, \mathrm{Cr}, \mathrm{Co}, \mathrm{Cu}, \mathrm{Zn}$ and $\mathrm{Pb}$ concentrations were determined using atomic absorption spectrometry. Total coliforms and E. coli were determined through inoculation. The results revealed TDS were generally within the recommended level (1200 $\mathrm{mg} / \mathrm{l}$ ), except the raw influent, which recorded $1582 \mathrm{mg} / \mathrm{l}$. Range in $\mathrm{Al}, \mathrm{Cd}, \mathrm{Cr}, \mathrm{Co}, \mathrm{Cu}$ and $\mathrm{Zn}$ was $2.8-13 \mathrm{mg} / \mathrm{l}, 3.6-4.2 \mathrm{mg} / \mathrm{l}$, 1.2 - $5.0 \mathrm{mg} / \mathrm{l}, 3.2-5 \mathrm{mg} / \mathrm{l}, 0.4-5.0 \mathrm{mg} / \mathrm{l}, 0.4-6.8 \mathrm{mg} / \mathrm{l}$, respectively. Lead with a concentration of $6.8 \mathrm{mg} / \mathrm{l}$ was detected only in the treated effluent sample. Recommended concentrations of $\mathrm{Al}, \mathrm{Cd}, \mathrm{Cr}, \mathrm{Co}, \mathrm{Cu}, \mathrm{Zn}$ and $\mathrm{Pb}$ are 5, 0.5, 1.5, 0.1, 0.05, 2 and 5 $\mathrm{mg} / \mathrm{l}$, respectively. It was further observed total coliforms and Escherichia coli in the samples exceeded recommended concentrations of $<1000$ minimum probable number per litre (< $1000 \mathrm{MPN} / \mathrm{l}$ ) and nil/ $100 \mathrm{ml}$, respectively. The results showed that most of parameters measured exceeded the recommended water quality limits. Therefore, the wastewater cannot for crop irrigation.
\end{abstract}

Index Terms- Urban agriculture, heavy metals, bioaccumulation, contaminants, health risks

\section{INTRODUCTION}

$\mathrm{T}$ he volume of wastewater generated by domestic, industrial and commercial sources has increased with population, urbanization, improved living conditions and economic development. The productive use of wastewater has also increased, as millions of small- scale farmers in urban and periurban areas of developing countries depend on wastewater or wastewater-polluted water sources to irrigate high- value edible crops for urban markets, often as they have no alternative sources of irrigation water (Qadir, et al., 2010). In most developing countries, large volumes of urban wastewater generated remain untreated due to inadequate resources for effective wastewater treatment facilities (Drechsel, et al., 2010).

Wastewater generated from various sources transport substantial amounts of toxic heavy metals that can contaminate agricultural soils. Continuous application of municipal or industrial wastewater for irrigation brings about build-up of trace elements such as $\mathrm{Cd}, \mathrm{Cu}, \mathrm{Zn}, \mathrm{Cr}$ and $\mathrm{Pb}$ in the soil surface. Their excessive accumulation not only contaminates the soil but also affect the quality and safety of food crops (Gezahegn et al., 2017). Key sources of chemical pollutants that pose risk to human health are municipal and industrial wastewater (Buechler et al., 2006).

Although reuse of wastewater for irrigation represents an additional source of those available to overcome existing gap in quantity of irrigation water in Egypt, evaluation of suitability of wastewater for irrigation should be carried out periodically in view of variations of amounts and types of contaminants disposed in such water (Abbas et al., 2015).

One of the most limiting factors for agricultural use of wastewater is the presence of heavy metals, which are introduced by discharging untreated industrial effluents into municipal sewer. Repeated application of sewage effluents to agricultural land could also lead to accumulation of metals in the soil as it is an important sink for heavy metals due to its high retention capacity (Bashir $e t$ al., 2009). Heavy metals (Naser et al., 2012) have a tendency to bio-accumulate in plants and animals, and bio-concentrate in the food chain and attack specific body organs. The contamination may be triggered by irrigation with contaminated water, 
application of fertilizers and metal-based pesticides, industrial emissions, transportation, harvesting process, and storage and /or sale (Bagdatlioglu et al., 2010).

Heavy metals enter human body via food, drinking water and air. Consumers' demand for better quality vegetable is increasing. To some, undamaged, dark green and big leaves are characteristics of good quality leafy vegetables. However, the external morphology of vegetables cannot guarantee safety from contamination. Heavy metals rank high amongst the chief contaminants of leafy vegetables. Vegetables take up metals by absorbing them from contaminated soils, as well as from polluted environments. Vegetables growing on heavy metal contaminated medium can accumulate high concentrations of trace elements and cause health risk to consumers (Ali and Al-Qahtani, 2012). In low concentrations, many metals are essential to life. For instance, trace quantities of certain heavy elements like $\mathrm{Co}, \mathrm{Cu}$ and $\mathrm{Zn}$ are essential micronutrients for plants and higher animals. However, excessive accumulation in agricultural soils through wastewater irrigation may not only result in soil contamination, but it also affects food quality and safety (Naser et al., 2018).

A survey conducted between 2006 and 2007 by Kaluli, et al. (2011) showed nearly half of the wastewater generated in Nairobi, Kenya ended up treated in the treatment facilities, while raw sewage was used for irrigating more than 720 hectares (ha) of cropland. Crops grown include vegetables such as Brassica sp., Spinacia sp. and the African vegetables like Amaranthus sp. Wastewater generated in Nairobi falls within the Environmental Management and Coordination (Water Quality) Regulations, 2006 except biological oxygen demand and coliform bacteria in raw sewage. Nairobi City's untreated wastewater is discharged through natural drainage waterways, hence most freshwater resources are polluted to varying degrees. Urban and peri-urban farmers in the City irrigate their vegetables with the untreated wastewater (Ndunda and Mungatana, 2013).

Municipal wastewater as a medium consisting of water, and organic and mineral substances characterized by negligible temperature variations, provides favourable conditions for the development, existence and survival of fungi, viruses and bacteria as well as pathogenic organisms (Bawiec et al., 2016). According to Hussain et al., (2002), pathogenic microorganisms in wastewater that are potential of causing disease are bacteria, viruses and parasites. Many pathogens can survive for long enough in soil or on crop surfaces and are transmitted to human beings or animals. The most environmentally resistant pathogens are helminth eggs recognized as the main health risk in the use of wastewater for irrigation. Other diseases related to the use of wastewater include cholera, typhoid, gastric ulcers caused by Helicobacter pylori, and amebiasis (Jiménez, 2006). Although coliforms commonly occur in water, they are generally not harmful to human. Their presence is used as an indicator for water contamination with diseases causing germs and pathogens (Abbas et al., 2015).

Levels of faecal coliforms in water used for irrigation often exceed the WHO (2006) wastewater irrigation guidelines. Irrigation with untreated water and wastewater is one source of microbial contamination of vegetables along the production chain. Other sources include pathogens in the soil, application of contaminated manure, and cleaning the vegetable produce with polluted water. In the case of vegetables produced in urban areas the main microbial contamination occurs during primary production thereby suggesting post-harvest processing and handling do not necessarily increase contamination levels (Magnusson and Bergman, 2014).

Non-spore-forming gram-negative bacterium like Escherichia coli is the most common cause of acute urinary tract infections. It may also cause acute enteritis in human beings and animals and is a general cause of a dysentery-like disease affecting human beings, and haemorrhagic colitis often referred to as 'bloody diarrhoea' (Percival and Williams, 2014).

The chemical characteristics of recycled water are crucial for understanding the environmental effects, while the biological aspect is important when health effects are considered (Maheshwari, 2016). The objective of the study was to examine the physicochemical characteristics and microbiological composition of the treated effluent, raw influent and wastewaterpolluted water sources used for vegetable crop irrigation in Ruai ward, Nairobi County, Kenya. Respective samples were analysed for physicochemical chemical characteristics viz. total dissolved solids (TDS), aluminium ( $\mathrm{Al})$, cadmium $(\mathrm{Cd})$, chromium $(\mathrm{Cr})$, cobalt $(\mathrm{Co})$, copper $(\mathrm{Cu})$, zinc $(\mathrm{Zn})$ and lead $(\mathrm{Pb})$. They were also analysed for microbiological composition viz. total coliforms and Escherichia coli. Values obtained were compared with values for corresponding parameters in the Environmental Management and Coordination (Water Quality) Regulations, 2006.

\section{MATERIALS AND METHODS}

\section{Description of study area}

The study was carried out in Ruai ward, which is an urban and peri-urban setting in Nairobi County, Kenya. Nairobi, the capital City of Kenya, has a population of 4.3 million people (KNBS, 2019). The City is lies between latitude $1^{\circ} 16^{\prime}$ South and longitude $36^{\circ} 48^{\prime}$ East, $148 \mathrm{Km}$ south of the Equator. It is located at an altitude of 1,680 metres above sea level and covers an area of $689 \mathrm{~km}^{2}$ (Fig. 1). 


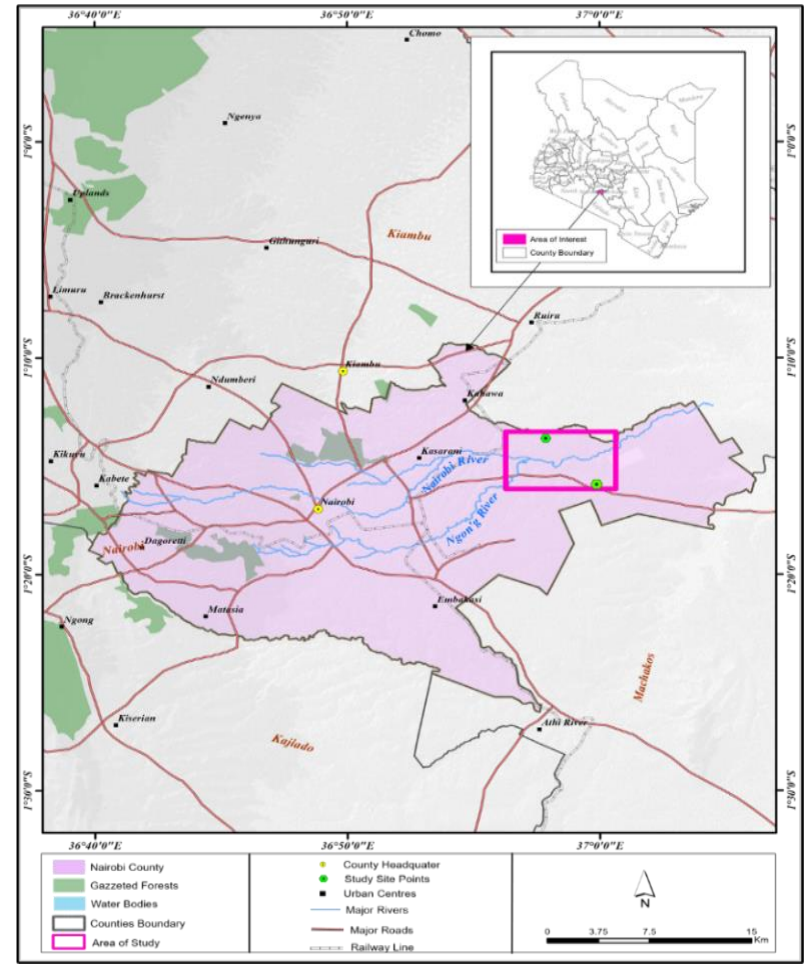

Figure 1: Map of Kenya showing location of study area

Nairobi enjoys a warm tropical highland climate. Average daily temperatures range from $29^{\circ} \mathrm{C}$ in the dry season to $24^{\circ} \mathrm{C}$ during the rest of the year. The average annual rainfall is $875 \mathrm{~mm}$ (Omwenga, 2011). There are two rainy seasons, short and long, which occur in October- December and March-May, respectively. The Nairobi River is used downstream by close to 4 million people for irrigation and domestic purposes. It traverses through Nairobi City and has three tributaries viz. Mathare, Nairobi and Ngong rivers which pass through numerous informal settlements such as Mathare valley, Korogocho, Majengo, Dandora and Kariobangi South whose sewerage and solid waste disposal systems are inadequate. The tributaries are surrounded by small-scale farms producing fresh vegetables (Njuguna et al., 2017).

\section{Sampling Procedure}

Identification of Sampling Sites

A preliminary survey of the study area was conducted in February 2018 and sources of water used for irrigation were identified with the help of 177 out of 250 farmers interviewed between March and August 2018. Sources of water used for irrigation were categorized into the treated effluent, raw influent and wastewater-polluted water sources. The latter, which comprised of the Nairobi River was further categorized into discharge point where the treated effluent discharges into the Nairobi River, upstream and downstream. These sources became the study's sampling points from where the sampling sites were randomly selected and georeferenced.

\section{Sampling}

Each sampling point was sampled twice by dipping the sample bottle approximately $20-30 \mathrm{~cm}$ below water surface, while directing the bottles' mouth against the flow direction. All samples were collected at points closest to where it is either pumped or directed on to the vegetable farmlands. The samples were collected once (grab samples) from five predetermined and georeferenced sampling points. Eaton (2005) is of the view that sources such as large lakes, protected groundwater supplies, water supplies receiving conventional treatment and wastewater streams may be adequately represented by single grab samples. It was therefore presumed each sample taken represented the composition of its source.

Care was taken to ensure nothing was in contact with the insides of the bottles and lids to avoid or minimize contamination. In collecting and preparing the samples for analysis, precautionary measures were observed at all times. The two-litre plastic bottles were first cleaned with clean water and rinsed thrice with respective sample before filling. Each sample collected as discrete sample was kept in respective bottle. The first set of samples clearly marked with the geographical location of each sampling point (Table 1) were kept on ice and transported to the Directorate of Mines and Geology laboratory for analysis of TDS, Al, Cd, Cr, $\mathrm{Co}, \mathrm{Cu}, \mathrm{Zn}$ and $\mathrm{Pb}$ concentrations.

\section{Table 1: Sampling sites and coordinates of sampling points}

\begin{tabular}{lll}
\hline Entry & Sampling site & Sampling point coordinates \\
\hline 1 & Treated effluent & $1^{\circ} 14^{\prime} 24^{\prime \prime} \mathrm{S}$ (Latitude), $37^{\circ}$ \\
& & $00^{\prime} 25^{\prime \prime} \mathrm{E}$ (Longitude) \\
2 & Discharge point & $1^{\circ} 14^{\prime} 35^{\prime \prime} \mathrm{S}$ (Latitude), $37^{\circ}$ \\
& & $00^{\prime} 27^{\prime \prime} \mathrm{E}$ (Longitude) \\
3 & Upstream Nairobi & $1^{\circ} 21^{\prime} 46^{\prime \prime} \mathrm{S}$ (Latitude), $36^{\circ}$ \\
& River & $58^{\prime} 48^{\prime \prime} \mathrm{E}$ (Longitude) \\
4 & Raw influent & $1^{\circ} 15^{\prime} 08^{\prime \prime} \mathrm{S}$ (Latitude), $36^{\circ}$ \\
& & $55^{\prime} 35^{\prime \prime} \mathrm{E}$ (Longitude) \\
5 & Downstream Nairobi & $1^{\circ} 14^{\prime} 30^{\prime \prime} \mathrm{S}$ (Latitude), $36^{\circ}$ \\
& River & $55^{\prime} 53^{\prime \prime} \mathrm{E}$ (Longitude) \\
\hline
\end{tabular}

The second set of samples clearly marked with the geographical location of each sampling point (Table 2) were kept on ice and transported to the Central Water Testing Laboratory at the Water Resources Authority for analysis of total coliforms and Escherichia coli concentrations. 
Table 2: Sampling sites and coordinates of sampling points

\begin{tabular}{lll}
\hline Entry & Sampling site & Sampling point coordinates \\
\hline 1. & Treated effluent & $1^{\circ} 14^{\prime} 10^{\prime \prime} \mathrm{S}$ (Latitude), $37^{\circ} 00^{\prime} 49^{\prime \prime} \mathrm{E}$ (Longitude) \\
2. & $1^{\circ} 14^{\prime} 6^{\prime \prime} \mathrm{S}$ (Latitude), $37^{\circ} 00^{\prime} 50^{\prime \prime} \mathrm{E}$ (Longitude) \\
3. & Discharge point & $1^{\circ} 14^{\prime} 40^{\prime \prime} \mathrm{S}$ (Latitude), $36^{\circ} 57^{\prime} 14^{\prime \prime} \mathrm{E}$ (Longitude) \\
4. & Upstream of Nairobi River & $1^{\circ} 14^{\prime} 46^{\prime \prime} \mathrm{S}$ (Latitude), $36^{\circ} 55^{\prime} 34^{\prime \prime} \mathrm{E}$ (Longitude) \\
5. & Raw influent & \\
& Downstream of Nairobi River & $1^{\circ} 14^{\prime} 36^{\prime \prime} \mathrm{S}$ (Latitude), $36^{\circ} 56^{\prime} 06^{\prime \prime} \mathrm{E}$ (Longitude)
\end{tabular}

The study used experimental research design because samples of the treated effluent, raw influent and wastewaterpolluted water sources viz. discharge point, upstream and downstream Nairobi River used for irrigating vegetables in the study area were analysed in the laboratory using standard methods to determine physicochemical characteristics and microbiological composition.

\section{Data analysis}

The samples delivered to the Directorate of Mines and Geology laboratory were analysed for TDS, $\mathrm{Al}, \mathrm{Cd}, \mathrm{Cr}, \mathrm{Co}, \mathrm{Cu}$, $\mathrm{Zn}$ and $\mathrm{Pb}$ concentrations using standard methods described by Eaton (2005). The resultant values for the analyses were compared with recommended values for corresponding parameters in the Environmental Management and Coordination (Water Quality) Regulations, 2006 standards for irrigation water. The samples delivered to the Central Water Testing Laboratory were analysed for total coliforms and Escherichia coli using standard methods described by Eaton (2005). While in the laboratory, the samples were inoculated aseptically and incubated for $18-24$ hours to prevent cross contamination from other sources and to ensure the results obtained were actual. During inoculation coliform organisms were determined using substrate enzyme defined technique method (Colilert -18), which simultaneously detected both total coliforms and $E$. coli in a $250 \mathrm{~mL}$ format.

Data for the treated effluent sample was subjected to one way ANOVA for analysis of variance to compare the concentration of the analysed parameters (Glenda, 2012) against the Environmental Management and Coordination (Water Quality) Regulations 2006 standards for irrigation water. It was further analysed using the Bonferroni post hoc test (Ware, et al., 2013) to show difference in mean concentration against the Environmental Management and Coordination (Water Quality) Regulations, 2006 standards for irrigation water.

\section{RESULTS}

\section{Treated effluent sample}

Table 3: Concentrations of TDS, $\mathrm{Al}, \mathrm{Cd}, \mathrm{Cr}, \mathrm{Co}, \mathrm{Cu}, \mathrm{Zn}$ and $\mathrm{Pb}$ in the treated effluent sample

\begin{tabular}{|c|c|c|c|c|}
\hline Sampling site & $\begin{array}{l}\text { Sampling point } \\
\text { coordinates }\end{array}$ & Parameter & Concentration (mg/l) & EMCR \\
\hline Treated effluent & $\begin{array}{l}1^{\circ} 14^{\prime} 24^{\prime \prime} \\
37^{\circ} \quad 00^{\prime} \quad 25^{\prime \prime} \quad \mathrm{Eat} \text { ) } \\
\text { (Long.) }\end{array}$ & $\begin{array}{l}\mathrm{Al} \\
\mathrm{Cd} \\
\mathrm{Cr} \\
\mathrm{Co} \\
\mathrm{Cu} \\
\mathrm{Zn} \\
\mathrm{Pb} \\
\mathrm{TDS}\end{array}$ & $\begin{array}{l}13.0 \\
3.6 \\
5.0 \\
5.0 \\
4.2 \\
3.0 \\
6.8 \\
788\end{array}$ & $\begin{array}{l}5 \\
0.5 \\
1.5 \\
0.1 \\
0.05 \\
2 \\
5 \\
1200\end{array}$ \\
\hline
\end{tabular}

Where, $\mathrm{EMCR}$ = Environmental Management and Coordination (Water Quality) Regulations, 2006 standards for irrigation water

The findings of the study showed that there is no significant variation between the groups, $p=0.07261$ (Table 4). 
Table 4: Analysis between variables

\begin{tabular}{llllll}
\hline Source of variation & Df & SS & MS & F & p- value \\
\hline Between groups & 1 & $\mathbf{9 2 9 0 . 5 5}$ & 9290.55 & $\mathbf{0 . 0 7 2 6 1}$ & $\mathbf{0 . 7 9 1 5}$ \\
Within groups & 14 & 1791213 & 127944 & & \\
Total & 15 & 1800504 & & & \\
\hline
\end{tabular}

Further analysis using the Bonferroni correction (Ware, et al., 2013) showed no significant difference in the means of the concentration of analysed parameters in the sample tested against the Environmental Management and Coordination (Water Quality) Regulations, 2006 standards for irrigation water (Table 5).

Table 5: Bonferroni post hoc test showing difference in mean against Environmental Management and Coordination (Water Quality) Regulations, 2006 standards for irrigation water

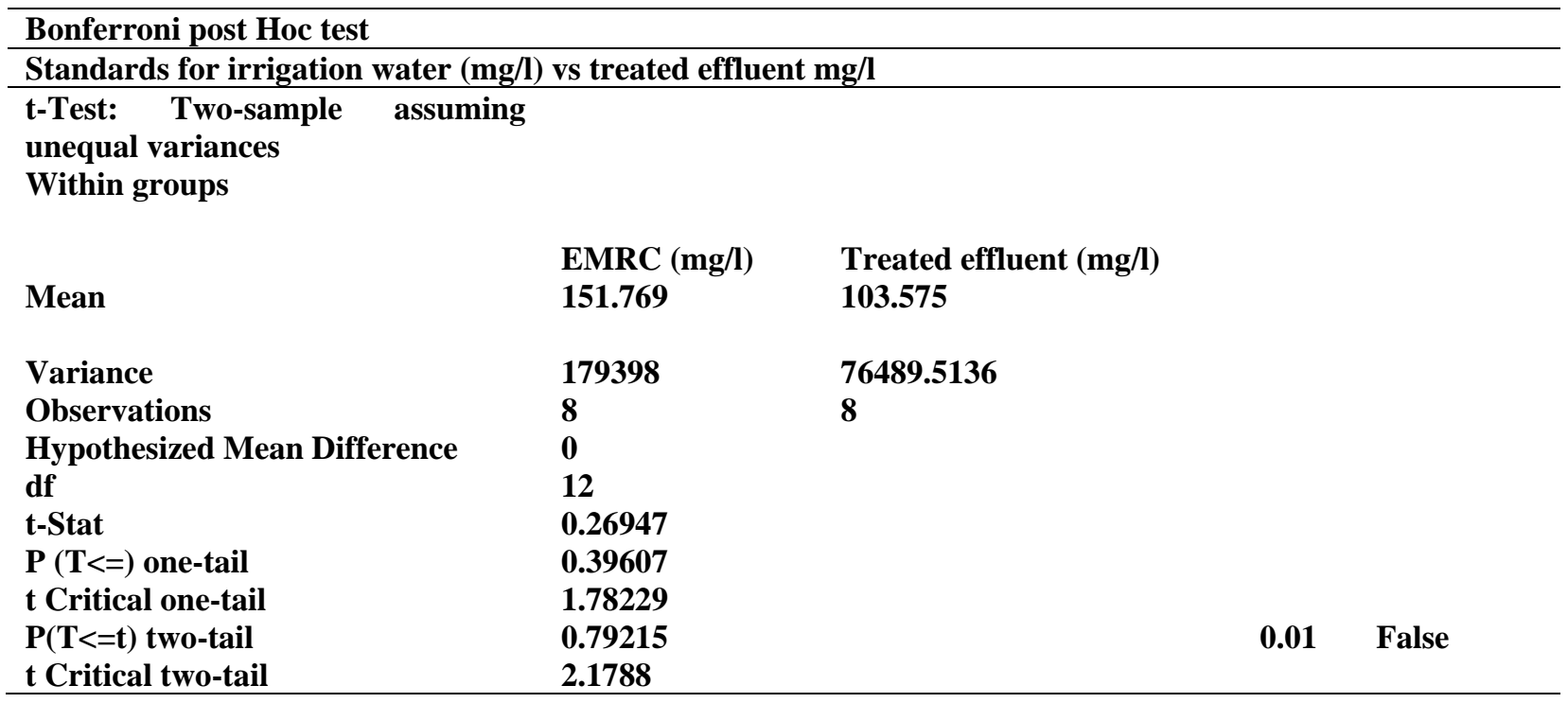

Where, EMCR = Environmental Management and Coordination (Water Quality) Regulations, 2006 standards for irrigation water

Discharge point sample

Table 6: Concentrations of TDS, Al, Cd, Cr, Co, $\mathrm{Cu}, \mathrm{Zn}$ and $\mathrm{Pb}$ in the discharge point sample

\begin{tabular}{lllll}
\hline Sampling site & Sampling point coordinates & Parameter & $\begin{array}{l}\text { Concentration } \\
(\mathbf{m g} / \mathbf{l})\end{array}$ & EMCR \\
& & & & \\
\hline Discharge point & $1^{\circ} 14^{\prime} 35^{\prime \prime} \mathrm{S}$ (Lat.) & $\mathrm{Al}$ & 2.8 & 5 \\
& & $\mathrm{Cd}$ & 3.8 & 0.5 \\
& $37^{\circ} 00^{\prime} 27^{\prime \prime} \mathrm{E}$ (Long.) & $\mathrm{Cr}$ & 4.0 & 1.5 \\
& & $\mathrm{Co}$ & 4.0 & 0.1 \\
& $\mathrm{Cu}$ & 3 & 2 \\
& & $\mathrm{Zn}$ & 6.8 & 5 \\
& $\mathrm{~Pb}$ & $\mathrm{ND}$ & 1200 \\
\hline
\end{tabular}

Where, EMCR = Environmental Management and Coordination (Water Quality) Regulations, 2006 standards for irrigation water The findings of the study showed that there is no significant variation between the groups, $\mathrm{p}=0.65417$ (Table 7 ). 
Table: 7: Analysis between variables

\begin{tabular}{llllll}
\hline Source of Variation & Df & SS & MS & F & p-value \\
\hline Between Groups & 1 & 23161 & 23161 & 0.20951 & 0.65417 \\
Within Groups & 14 & 1547643 & 110546 & & \\
Total & 15 & 1570804 & & & \\
\hline
\end{tabular}

Further analysis of the results showed no significant difference in the means of the concentration of analysed parameters in the sample at discharge point against the Environmental Management and Coordination (Water Quality) Regulations, 2006 standards for irrigation water (Table 8).

Table 8: Bonferroni post hoc test showing difference in mean against Environmental Management and Coordination (Water Quality) Regulations, 2006 standards for irrigation water

Bonferroni post Hoc test

Standards for irrigation water (mg/l) vs treated effluent $\mathrm{mg} / \mathrm{l}$

t-Test: Two-Sample Assuming Unequal

Variances

Discharge point sample

$\operatorname{EMCR}(\mathrm{mg} / \mathrm{l}) \quad(\mathrm{mg} / \mathrm{l})$

\begin{tabular}{|c|c|c|c|}
\hline Mean & 151.769 & 75.675 & \\
\hline Variance & 179398 & 41693.8 & \\
\hline Observations & 8 & 8 & \\
\hline Hypothesized Mean Difference & 0 & & \\
\hline Df & 10 & & \\
\hline t-Stat & 0.45773 & & \\
\hline $\mathrm{P}(\mathrm{T}<=\mathrm{t})$ one-tail & 0.32847 & & \\
\hline t- Critical one-tail & 1.81246 & & \\
\hline $\mathrm{P}(\mathrm{T}<=\mathrm{t})$ two-tail & 0.65693 & 0.01 & False \\
\hline t- Critical two-tail & 2.22814 & & \\
\hline
\end{tabular}

Upstream Nairobi River sample

Table 9: Concentrations of TDS, $\mathrm{Al}, \mathrm{Cd}, \mathrm{Cr}, \mathrm{Co}, \mathrm{Cu}, \mathrm{Zn}$ and $\mathrm{Pb}$ in the upstream Nairobi River sample

\begin{tabular}{|c|c|c|c|c|}
\hline Sampling site & $\begin{array}{l}\text { Sampling point } \\
\text { coordinates }\end{array}$ & Parameter & $\begin{array}{l}\text { Concentration } \\
\text { (mg/ l) }\end{array}$ & EMCR \\
\hline Upstream & $1^{\circ} 21^{\prime} 46^{\prime \prime} \mathrm{S}$ (Lat.) & $\mathrm{Al}$ & 13 & 5 \\
\hline \multirow[t]{7}{*}{ Nairobi River } & & $\mathrm{Cd}$ & 3.8 & 0.5 \\
\hline & $36^{\circ} 58^{\prime} 48^{\prime \prime} \mathrm{E}$ (Long.) & $\mathrm{Cr}$ & 4.4 & 1.5 \\
\hline & & $\mathrm{Co}$ & 3.6 & 0.1 \\
\hline & & $\mathrm{Cu}$ & 1.6 & 0.05 \\
\hline & & $\mathrm{Zn}$ & 5.6 & 2 \\
\hline & & $\mathrm{Pb}$ & ND & 5 \\
\hline & & TDS & 454 & 1200 \\
\hline
\end{tabular}

Where, EMCR = Environmental Management and Coordination (Water Quality) Regulations, 2006 standards for irrigation water

The findings of the study showed there is no significant variation between the groups $(\mathrm{p}=0.57833)$ as shown in Table 10 . 
Table 10: Analysis between variables

\begin{tabular}{llllll}
\hline Source of Variation & df & SS & MS & F & p-value \\
\hline Between Groups & 1 & 33137.7 & 33137.7 & 0.32383 & 0.57833 \\
Within Groups & 14 & 1432628 & 102331 & & \\
Total & 15 & 1465765 & & & \\
\hline
\end{tabular}

Further analysis showed no significance difference (Table 11) in the means of the concentration of the upstream Nairobi River samples against the Environmental Management and Coordination (Water Quality) Regulations, 2006 standards for irrigation water.

Table 11: Bonferroni post hoc test showing difference in mean against Environmental Management and Coordination (Water Quality) Regulations, 2006 standards for irrigation water

\begin{tabular}{lll}
\hline Bonferroni post Hoc test & \\
\hline \multicolumn{4}{l}{ Standards for irrigation water (mg/l) vs Upstream Nairobi River sample } \\
\hline $\mathrm{t}$-Test: Two-Sample Assuming Unequal Variances & $\begin{array}{l}\text { Standards for irrigation } \\
\text { water (mg/l) }\end{array}$ & $\begin{array}{l}\text { Upstream Nairobi River } \\
\text { Sample (mg/l) }\end{array}$ \\
\hline Mean & 151.769 & 60.75 \\
\hline Variance & 179398 & 25263 \\
\hline Observations & 8 & 8 \\
\hline Hypothesized Mean Difference & 0 & \\
\hline Df & 9 & \\
\hline $\mathrm{t}$ Stat & 0.56906 & \\
\hline $\mathrm{P}(\mathrm{T}<=\mathrm{t})$ one-tail & 0.29162 & \\
\hline $\mathrm{t}$ Critical one-tail & 1.83311 & \\
$\mathrm{P}(\mathrm{T}<=\mathrm{t})$ two-tail & 0.58324 & \\
\hline $\mathrm{t}$ Critical two-tail & 2.26216 & FALSE \\
\hline
\end{tabular}

Raw influent sample

Table 12: Concentrations of TDS, $\mathrm{Al}, \mathrm{Cd}, \mathrm{Cr}, \mathrm{Co}, \mathrm{Cu}, \mathrm{Zn}$ and $\mathrm{Pb}$ in the raw influent sample

\begin{tabular}{|c|c|c|c|c|}
\hline Sampling site & $\begin{array}{l}\text { Sampling } \\
\text { coordinates }\end{array}$ & Parameter & $\begin{array}{l}\text { Concentration } \\
(\mathrm{mg} / \mathrm{l})\end{array}$ & EMCR \\
\hline \multirow[t]{8}{*}{ Raw influent } & $1^{\circ} 15^{\prime} 08^{\prime \prime} \mathrm{S}$ (Lat.) & $\mathrm{Al}$ & 11 & 5 \\
\hline & $36^{\circ} 55^{\prime} 35^{\prime \prime} \mathrm{E}$ (Long.) & $\mathrm{Cd}$ & 3.8 & 0.5 \\
\hline & & $\mathrm{Cr}$ & 1.2 & 1.5 \\
\hline & & Co & 4 & 0.1 \\
\hline & & $\mathrm{Cu}$ & 5 & 0.05 \\
\hline & & $\mathrm{Zn}$ & 6.2 & 2 \\
\hline & & $\mathrm{Pb}$ & ND & 5 \\
\hline & & TDS & 1582 & 1200 \\
\hline
\end{tabular}

Where, EMCR = Environmental Management and Coordination (Water Quality) Regulations, 2006 standards for irrigation water

The sample's data was further subjected to one way ANOVA for analysis against the Environmental Management and Coordination (Water Quality) Regulations, 2006 standards for irrigation water and the results presented in Table 13. 
Table 13: Analysis between variables

\begin{tabular}{llllll}
\hline Source of Variation & df & SS & MS & F & p-value \\
\hline Between Groups & 1 & 9952.56 & 9952.56 & 0.04058 & 0.84324 \\
Within Groups & 14 & 3433425 & 245245 & & \\
Total & 15 & 3443378 & & & \\
\hline
\end{tabular}

Further analysis showed no significant different (Table 14) in the means of the sample concentration of raw influent against the Environmental Management and Coordination (Water Quality) Regulations, 2006 standards for irrigation water.

Table 14: Bonferroni post hoc test showing difference in mean against Environmental Management and Coordination (Water Quality) Regulations, 2006 standards for irrigation water

\begin{tabular}{|c|c|c|c|}
\hline Bonferroni post Hoc test & & & \\
\hline Standards for irrigation water ( & aw influent sample & & \\
\hline t-Test: Two-Sample Assuming L & Variances & & \\
\hline & $\begin{array}{l}\text { Standards for irrigation water } \\
(\mathrm{mg} / \mathrm{l})\end{array}$ & $\begin{array}{l}\text { Raw influent sample } \\
(\mathrm{mg} / \mathrm{l})\end{array}$ & \\
\hline Mean & 151.769 & 201.65 & \\
\hline Variance & 179398 & 311091 & \\
\hline Observations & 8 & 8 & \\
\hline Hypothesized Mean Difference & 0 & & \\
\hline Df & 13 & & \\
\hline t- Stat & -0.2015 & & \\
\hline $\mathrm{P}(\mathrm{T}<=\mathrm{t})$ one-tail & 0.42173 & & \\
\hline t- Critical one-tail & 1.77093 & & \\
\hline$P(T<=t)$ two-tail & 0.84346 & 0.01 & False \\
\hline t- Critical two-tail & 2.16037 & & \\
\hline
\end{tabular}

Downstream Nairobi River sample

Concentration of TDS in the sample was 496 against $1200 \mathrm{mg} / \mathrm{l}$ recommended in the Environmental Management and Coordination (Water Quality) Regulations, 2006 standards for irrigation water (Table 7).

Table 15: Concentrations of TDS, $\mathrm{Al}, \mathrm{Cd}, \mathrm{Cr}, \mathrm{Co}, \mathrm{Cu}, \mathrm{Zn}$ and $\mathrm{Pb}$ in the downstream Nairobi River sample

\begin{tabular}{|c|c|c|c|c|}
\hline Sampling site & $\begin{array}{l}\text { Sampling } \\
\text { coordinates }\end{array}$ & Parameter & $\begin{array}{l}\text { Concentration } \\
(\mathrm{mg} / \mathrm{l})\end{array}$ & EMCR \\
\hline Upstream & $1^{\circ} 14^{\prime} 30^{\prime \prime} \mathrm{S}$ (Lat.) & $\mathrm{Al}$ & 5.6 & 5 \\
\hline \multirow[t]{7}{*}{ Nairobi River } & $36^{\circ} 55^{\prime} 53^{\prime \prime} \mathrm{E}$ (Long.) & $\mathrm{Cd}$ & 4.2 & 0.5 \\
\hline & & $\mathrm{Cr}$ & 2.8 & 1.5 \\
\hline & & Co & 3.2 & 0.1 \\
\hline & & $\mathrm{Cu}$ & 0.4 & 0.05 \\
\hline & & $\mathrm{Zn}$ & 0.4 & 2 \\
\hline & & $\mathrm{Pb}$ & ND & 5 \\
\hline & & TDS & 496 & 1200 \\
\hline
\end{tabular}

Where, EMCR = Environmental Management and Coordination (Water Quality) Regulations, 2006 standards for irrigation water 
Copper and $\mathrm{Zn}$ recorded the same concentrations $(0.4 \mathrm{mg} / \mathrm{l})$ against 0.05 and $2 \mathrm{mg} / \mathrm{l}$, respectively. Concentration of $\mathrm{Cr}$ in the sample was $2.8 \mathrm{mg} / \mathrm{l}$, which exceeded the recommended $1.5 \mathrm{mg} / \mathrm{l}$. Cobalt concentration was $3.2 \mathrm{mg} / \mathrm{l}$ against $0.1 \mathrm{mg} / \mathrm{l}, 4.2 \mathrm{mg} / \mathrm{linstead}$ of 0.5 for $\mathrm{Cd}$, while $\mathrm{Al}$ concentration was $5.6 \mathrm{mg} / \mathrm{l}$ against recommended $5 \mathrm{mg} / \mathrm{l}$. Lead was not detected in the sample.

The sample's data was subjected to one way ANOVA for analysis and the results showed there is no significant variation between the groups $(\mathrm{p}=0.59672)$ as shown in Table 16.

Table 16: Analysis between variables

\begin{tabular}{llllll}
\hline Source of Variation & df & SS & MS & F & p-value \\
\hline Between Groups & 1 & 30760.8 & 30760.8 & 0.29315 & 0.59672 \\
Within Groups & 14 & 1469025 & 104930 & & \\
Total & 15 & 1499786 & & & \\
\hline
\end{tabular}

There is no significant difference in the mean of the sample tested against the Environmental Management and Coordination (Water Quality) Regulations, 2006 standards for irrigation water (Table 17).

Table 17: Bonferroni post hoc test showing difference in mean against Environmental Management and Coordination (Water Quality) Regulations, 2006 standards for irrigation water

\begin{tabular}{|c|c|c|c|c|}
\hline \multicolumn{5}{|l|}{ Bonferroni post Hoc test } \\
\hline \multicolumn{5}{|c|}{ Standards for irrigation water (mg/l) vs downstream Nairobi River sample } \\
\hline \multicolumn{5}{|c|}{ t-Test: Two-Sample Assuming Unequal Variances } \\
\hline & $\begin{array}{l}\text { Standards for irrigation water } \\
(\mathrm{mg} / \mathrm{l})\end{array}$ & $\begin{array}{l}\text { Downstream Nairobi } \\
(\mathrm{mg} / \mathrm{l})\end{array}$ & River & sample \\
\hline Mean & 151.769 & 64.075 & & \\
\hline Variance & 179398 & 30462.6507 & & \\
\hline Observations & 8 & 8 & & \\
\hline Hypothesized Mean Difference & 0 & & & \\
\hline Df & 9 & & & \\
\hline t- Stat & 0.54144 & & & \\
\hline $\mathrm{P}(\mathrm{T}<=\mathrm{t})$ one-tail & 0.30067 & & & \\
\hline t- Critical one-tail & 1.83311 & & & \\
\hline $\mathrm{P}(\mathrm{T}<=\mathrm{t})$ two-tail & 0.60135 & & 0.01 & False \\
\hline t- Critical two-tail & 2.26216 & & & \\
\hline
\end{tabular}

Results treated effluent, discharge point, upstream and downstream Nairobi River, and raw influent samples analysed for total coliforms and Escherichia coli concentrations against recommended values for corresponding microbiological organisms in the Environmental Management and Coordination (Water Quality) Regulations 2006 microbiological quality guidelines for wastewater use in irrigation

The raw influent sample recorded the highest $(2.420 \times 108$ cells/ $100 \mathrm{ml})$ concentration of total coliforms, while the downstream Nairobi River sample recorded the lowest (1.986 x 106 cells/ $100 \mathrm{ml}$ ) against less than 1000 minimum probable number per litre (mpn/l). The concentrations of total coliforms in the discharge point, treated effluent and upstream Nairobi River samples were 1.414 $\mathrm{x} 107$, $1.733 \times 107$ and $2.420 \times 107$, respectively (Table 18). 
Table 18: Concentrations of total coliforms in the treated effluent, discharge point, upstream and downstream Nairobi River, and raw influent samples

\begin{tabular}{|c|c|c|c|c|}
\hline Entry & Sampling site & $\begin{array}{l}\text { Sampling } \\
\text { coordinates }\end{array}$ & $\begin{array}{l}\text { Concentration } \\
(\mathrm{MPN} / \mathrm{l})\end{array}$ & EMCR \\
\hline 1. & Treated effluent & $\begin{array}{l}1^{\circ} 14^{\prime} 10^{\prime \prime} \mathrm{S} \text { (Lat.) } \\
37^{\circ} 00^{\prime} 49^{\prime \prime} \mathrm{E} \text { (Long.) }\end{array}$ & $1.733 \times 10^{7}$ & $<1000 \mathrm{mpn} / \mathrm{l}$ \\
\hline 2. & Discharge point & $\begin{array}{l}1^{\circ} 14^{\prime} 10^{\prime \prime} \mathrm{S} \text { (Lat.) } \\
37^{\circ} 00^{\prime} 49^{\prime \prime} \mathrm{E} \text { (Long.) }\end{array}$ & $1.414 \times 10^{7}$ & $<1000 \mathrm{mpn} / \mathrm{l}$ \\
\hline 3. & Upstream Nairobi River & $\begin{array}{l}1^{\circ} 14^{\prime} 40^{\prime \prime} \mathrm{S} \text { (Lat.) } \\
36^{\circ} 57^{\prime} 14^{\prime \prime} \mathrm{E} \text { (Long.) }\end{array}$ & $2.420 \times 10^{7}$ & $<1000 \mathrm{mpn} / \mathrm{l}$ \\
\hline 4. & Raw influent & $\begin{array}{l}1^{\circ} 14^{\prime} 46^{\prime \prime} \mathrm{S} \text { (Lat.) } \\
36^{\circ} 55^{\prime} 34^{\prime \prime} \mathrm{E} \text { (Long.) }\end{array}$ & $2.420 \times 10^{8}$ & $<1000 \mathrm{mpn} / \mathrm{l}$ \\
\hline 5. & $\begin{array}{l}\text { Downstream Nairobi } \\
\text { River }\end{array}$ & $\begin{array}{l}1^{\circ} 14^{\prime} 36^{\prime \prime} \mathrm{S} \text { (Lat.) } \\
36^{\circ} 56^{\prime} 06^{\prime \prime} \mathrm{E} \text { (Long.) }\end{array}$ & $1.986 \times 10^{6}$ & $<1000 \mathrm{mpn} / \mathrm{l}$ \\
\hline
\end{tabular}

Where, EMCR = Environmental Management and Coordination (Water Quality) Regulations, 2006 standards for irrigation water, $\mathrm{mpn} / \mathrm{l}$ $=$ Minimum probable number

Data of total coliforms in the sample was subjected to one way ANOVA for analysis of variance and the results are presented in Table 19. The $\mathrm{p}$ - value comparing the interaction between the total coliforms cells in the samples tested against the Environmental Management and Coordination (Water Quality) Regulations, 2006 microbiological quality guidelines for wastewater use in irrigation is 0.225735058 .

Table 19: Analysis between variables

\begin{tabular}{llllll}
\hline Source of Variation & df & SS & MS & F & p-value \\
\hline Between Groups & 1 & $8.97907 \mathrm{E}+15$ & $8.97907 \mathrm{E}+15$ & 1.7228058 & 0.225735058 \\
Within Groups & 14 & $4.16951 \mathrm{E}+16$ & $5.21189 \mathrm{E}+15$ & & \\
Total & 15 & $5.06742 \mathrm{E}+16$ & & & \\
\hline
\end{tabular}

It is higher than 0.05 , indicating no significance in the interaction between total coliforms in the samples and microbiological quality guidelines for wastewater use in irrigation. The means for the variables show a higher concentration of total coliforms in the samples tested which exceeded what is recommend in the guidelines (Table 20).

Table 20: Bonferroni post hoc test showing difference in mean against Environmental Management and Coordination (Water Quality) Regulations, 2006 microbiological quality guidelines for wastewater use in irrigation

\begin{tabular}{|c|c|c|c|}
\hline \multicolumn{4}{|l|}{ Bonferroni post Hoc test } \\
\hline \multicolumn{4}{|c|}{ Standards for irrigation water $(\mathrm{mg} / \mathrm{l})$ Total coliform cells } \\
\hline \multicolumn{4}{|c|}{ t-Test: Two-Sample Assuming Unequal Variances } \\
\hline & $\begin{array}{l}\text { Total coliforms } \\
\text { Cells/ } 100 \mathrm{ml}\end{array}$ & $\operatorname{EMCR}(<1000 \mathrm{mpn})$ & \\
\hline Mean & 59931200 & 1000 & \\
\hline Variance & $1.04 \mathrm{E}+16$ & 0 & \\
\hline Observations & 5 & 5 & \\
\hline Hypothesized Mean Difference & $5.21 \mathrm{E}+15$ & & \\
\hline Df & 0 & & \\
\hline $\mathrm{t}$ - Stat & 8 & & \\
\hline $\mathrm{P}(\mathrm{T}<=\mathrm{t})$ one-tail & 1.312557 & & \\
\hline
\end{tabular}




\begin{tabular}{ll|l|l}
\hline $\mathrm{T}-$ Critical one-tail & 0.112868 & & \\
\hline $\mathrm{P}(\mathrm{T}<\mathrm{t})$ two-tail & 1.859548 & & 0.25 \\
\hline $\mathrm{t}-$ Critical two-tail & 0.225735 & & \\
\hline
\end{tabular}

The concentration of Escherichia coli in the samples ranged from $1.733 \times 10^{6}$ in the downstream Nairobi River sample, $9.2 \times 10^{6}$ in the discharge point sample, $1.203 \times 10^{7}$ in the treated effluent sample, $1.733 \times 10^{7}$ in the upstream Nairobi River sample, to $2.420 \times$ $10^{7}$ in the raw influent sample (Table 20).

Table 20: Concentration of Escherichia coli cells in the treated effluent, discharge point, upstream and downstream Nairobi River, and raw influent samples

\begin{tabular}{|c|c|c|c|c|}
\hline Entry & Sampling site & $\begin{array}{l}\text { Sampling } \\
\text { coordinates }\end{array}$ & $\begin{array}{l}\text { Concentration } \\
(\mathrm{mpn} / \mathrm{l})\end{array}$ & EMCR \\
\hline 1. & Treated effluent & $\begin{array}{l}1^{\circ} 14^{\prime} 10^{\prime \prime} \mathrm{S} \text { (Lat.) } \\
37^{\circ} 00^{\prime} 49^{\prime \prime} \mathrm{E} \text { (Long.) }\end{array}$ & $1.203 \times 10^{7}$ & $<1000 \mathrm{mpn} / \mathrm{l}$ \\
\hline 2. & Discharge point & $\begin{array}{l}1^{\circ} 14^{\prime} 10^{\prime \prime} \mathrm{S} \text { (Lat.) } \\
37^{\circ} 00^{\prime} 49^{\prime \prime} \mathrm{E} \text { (Long.) }\end{array}$ & $9.2 \times 10^{6}$ & $<1000 \mathrm{mpn} / \mathrm{l}$ \\
\hline 3. & Upstream Nairobi River & $\begin{array}{l}1^{\circ} 14^{\prime} 40^{\prime \prime} \text { S (Lat.) } \\
36^{\circ} 57^{\prime} 14^{\prime \prime} \text { E (Long.) }\end{array}$ & $1.733 \times 10^{7}$ & $<1000 \mathrm{mpn} / \mathrm{l}$ \\
\hline 4. & $\begin{array}{l}\text { Raw influent } \\
\text { Downstream Nairobi }\end{array}$ & $\begin{array}{l}1^{\circ} 14^{\prime} 46^{\prime \prime} \mathrm{S} \text { (Lat.) } \\
36^{\circ} 55^{\prime} 34^{\prime \prime} \mathrm{E} \text { (Long.) }\end{array}$ & $2.420 \times 10^{7}$ & $<1000 \mathrm{mpn} / \mathrm{l}$ \\
\hline 5. & River & $\begin{array}{l}1^{\circ} 14^{\prime} 36^{\prime \prime} \mathrm{S} \text { (Lat.) } \\
36^{\circ} 56^{\prime} 06^{\prime \prime} \mathrm{E} \text { (Long.) }\end{array}$ & $1.733 \times 10^{6}$ & $<1000 \mathrm{mpn} / \mathrm{l}$ \\
\hline
\end{tabular}

Where, EMCR = Environmental Management and Coordination (Water Quality) Regulations, 2006 standards for irrigation water, ppn/1 $=$ Minimum probable number

Data of Escherichia coli was subjected to one way ANOVA with variance for analysis to compare the results of the samples against the Environmental Management and Coordination (Water Quality) Regulations, 2006 microbiological quality guidelines for wastewater use in irrigation and the results presented in Table 21.

Table 21: Analysis between variables

\begin{tabular}{llllll}
\hline Source of Variation & df & SS & MS & F & p-value \\
\hline Between Groups & 1 & $4.15935 \mathrm{E}+14$ & $4.15935 \mathrm{E}+14$ & 11.61571 & 0.009247947 \\
Within Groups & 14 & $2.86464 \mathrm{E}+14$ & $3.5808 \mathrm{E}+13$ & & \\
Total & 15 & $7.02398 \mathrm{E}+14$ & & & \\
\hline
\end{tabular}

The p-value comparing the interaction between the Escherichia coli cells in the samples tested against the Environmental Management and Coordination (Water Quality) Regulations, 2006 microbiological quality guidelines for wastewater use in irrigation is 0.009247947. It is lower than 0.05, indicating a significant interaction between the Escherichia coli cells in the samples tested and the microbiological quality guidelines for wastewater use in irrigation.

There is a significance difference (Table 22) in the means of the variables indicating the Escherichia coli cells are significantly higher in the samples tested than what the guidelines recommend, which is Nil/100ml. 
Table 22: Bonferroni post hoc test showing difference in mean against Environmental Management and Coordination (Water Quality) Regulations, 2006 microbiological quality guidelines for wastewater use in irrigation

\begin{tabular}{|c|c|c|c|}
\hline \multicolumn{4}{|l|}{ Bonferroni post Hoc test } \\
\hline \multicolumn{4}{|c|}{ Standards for irrigation water $(\mathrm{mg} / \mathrm{l})$ vs E.coli Cells } \\
\hline \multicolumn{4}{|c|}{$\begin{array}{l}\text { t-Test: Two-Sample Assuming } \\
\text { Equal Variances }\end{array}$} \\
\hline & E. coli cells/ ml & $\begin{array}{lr}\text { Standard } & \text { for } \\
\text { irrigation } & \text { water } \\
(\mathrm{Nil} / 100 \mathrm{ml}) & \end{array}$ & \\
\hline Mean & 12898600 & 0 & \\
\hline Variance & $7.16 \mathrm{E}+13$ & 0 & \\
\hline Observations & 5 & 5 & \\
\hline Pooled Variance & $3.58 \mathrm{E}+13$ & & \\
\hline Hypothesized Mean Difference & 0 & & \\
\hline Df & 8 & & \\
\hline t Stat & 3.408182 & & \\
\hline $\mathrm{P}(\mathrm{T}<=\mathrm{t})$ one-tail & 0.004624 & & \\
\hline t Critical one-tail & 1.859548 & & \\
\hline $\mathrm{P}(\mathrm{T}<=\mathrm{t})$ two-tail & 0.009248 & 0.025 & True \\
\hline t Critical two-tail & 2.306004 & & \\
\hline
\end{tabular}

\section{DISCUSSION}

In Kaluli, et al. (2011) farmers mainly use municipal and industrial wastewater as well as raw influent for irrigation. This is confirmed by a brief field survey conducted to establish sources of water used for irrigating vegetables in the study area. In Buechler et al. (2006) municipal and industrial wastewater are main sources of chemical pollutants that pose risk to human health.

In most samples $\mathrm{Cd}, \mathrm{Cu}, \mathrm{Zn}, \mathrm{Cr}$ and $\mathrm{Pb}$ concentrations exceeded the recommended values for corresponding elements in the Environmental Management and Coordination (Water Quality) Regulations, 2006 standards for irrigation water. This could be associated with continuous use of raw influent and wastewater-polluted water sources as study revealed elevated levels of $\mathrm{Cd}, \mathrm{Cu}$, Continuous application of municipal or industrial wastewater for irrigation brings about build-up of trace elements such as in the soil surface and their excessive accumulation not only contaminates the soil but also affect the quality and safety of food (Gezahegn et al., 2017). Our findings showed $\mathrm{Cd}, \mathrm{Cu}, \mathrm{Zn}, \mathrm{Cr}$ and $\mathrm{Pb}$ concentrations in most samples surpassed the recommended levels recommended in the standards for irrigation water, which confirms Gezahegn et al. (2017).

Poyen et al (2019) is of the view that quality of irrigation water is one of the factors that lower crop productivity. The authors are of the view the Kenya's Environmental Management and Coordination (Water Quality) Regulations, 2006 not only aims at protecting the environment and health safety; but also improvement of crop productivity.
Values for TDS in the samples were generally below the recommended limit of $1200 \mathrm{mg} / \mathrm{l}$ in the standards for irrigation water, which confirms findings by Mbui et al. (2017). Higher TDS value in the raw influent (1582) could be associated with leachate resulting from solid waste disposal into the Nairobi River. Conversely lower TDS values recorded in the upstream and downstream Nairobi River of 454 and $496 \mathrm{mg} / \mathrm{l}$, respectively, could be linked to reduced erosion of land upstream, and reduced discharge.

Aluminium concentration in the samples was highest (13 $\mathrm{mg} / \mathrm{l}$ ) in both treated effluent and upstream Nairobi River samples. This value exceeds $5 \mathrm{mg} / \mathrm{l}$ recommended in the standards for irrigation water. Jeong, et al. (2016) are of the view Cd when dissolved in water or soil, it can be accumulated in the crop and becomes harmful to the human body. With respect to $\mathrm{Cd}$, none of the five samples met the standard for irrigation water. The Nairobi River is recipient of both solid waste, as well as treated and untreated wastewater. The study considered the section of the River prior to receiving the treated effluent as upstream. The water has high level of chromium and high level of chromium water has been found to cause dermatitis disease (Karanja et al (2016).

The mean value for Cobalt in the samples exceeded the recommended cobalt limits in the standards irrigation water. Excessive accumulation in agricultural soils through wastewater irrigation may not only result in soil contamination, but also affects food quality and safety (Naser et al., 2018). The elevated Co concentration in the treated effluent could be linked to effluent discharges into the Nairobi River from small and medium enterprises such as vehicle garages. 
The samples' mean value for surpassed the recommended $\mathrm{Cu}$ limits in the standards for irrigation water. Excessive accumulation of trace elements such as $\mathrm{Cu}$ not only contaminates the soil but also affect the quality and safety of food crops (Gezahegn et al., 2017). The mean value for $\mathrm{Zn}$ in the samples exceeded the recommended $\mathrm{Zn}$ limits in the standards irrigation water. Elevated levels of trace elements such as $\mathrm{Cu}$ and $\mathrm{Zn}$ can cause leaf chlorosis and the suppression of root growth as pointed out in Jeong et al (2016). Lead with a concentration of $6.8 \mathrm{mg} / \mathrm{l}$ against $5 \mathrm{mg} / \mathrm{l}$ recommended in the standards for irrigation water was detected only in the treated effluent sample, which implied that the treated effluent was suitable for irrigation.

The Ruai domestic wastewater and industrial wastewater treatment plant could not have been the only contributor of noted elevated levels of the analysed parameters in the samples from five sampling points in the study area. This is confirmed from the upstream Nairobi River sample, which showed that the River had high concentration of the analysed parameters before reaching the discharge point.

Overall assessment of the analysis results indicates none of the samples from the five different sampling sites met the Environmental Management and Coordination (Water Quality) Regulations, 2006 standards for irrigation water contrary to Kaluli et al. (2011). The findings also contradict Njenga et al. (2011) who discovered in their study that heavy metal loads in irrigation water were low. Despite undergoing treatment process, $\mathrm{Al}, \mathrm{Cd}, \mathrm{Cr}, \mathrm{Co}$, $\mathrm{Cu}, \mathrm{Zn}$ and $\mathrm{Pb}$ concentrations in the treated effluent sample surpassed the recommended values for corresponding parameters in the Environmental Management and Coordination (Water Quality) Regulations, 2006 standards for irrigation water.

Total coliforms and Escherichia coli were not only detected in all the samples, but their respective concentrations exceeded allowable limits of $<1000$ minimum probable number/litre and nil/ $100 \mathrm{ml}$, respectively. The p-value comparing the interaction between the Escherichia coli cells in the samples analysed against the Environmental Management and Coordination (Water Quality) Regulations, 2006 microbiological quality guidelines for wastewater use in irrigation was 0.009247947 . This was lower than 0.05 , which indicated a significant interaction between the Escherichia coli cells in the samples and the recommended quality guidelines recommended for wastewater use in irrigation. It further revealed a significance difference in the means of the variables indicating the Escherichia coli cells were significantly higher in the samples tested than what the guidelines recommend, which is Nil/100ml.

The findings concur with Kaluli et al (2011) that coliform bacteria in Nairobi's raw sewage (influent) surpassed the recommended level pursuant to Environmental Management and Coordination (Water Quality) Regulations, 2006 guidelines for wastewater use in irrigation. Of all the five sampling points corresponding to five sources of water used for vegetable production in the study area, the treated effluent despite undergoing treatment process, was exceedingly contaminated with high levels of total coliforms and Escherichia coli which renders it unsuitable for irrigation.

\section{CONCLUSION}

The increase in water pollution overtime has greatly contributed to unsafe crop irrigation water. This compromises environmental sustainability and health safety. With increased pollution from industries, vehicular emissions and untreated wastewater from households, more pollutants get deposited in water sources with resultant pollution of water used for irrigation. This leads to soil pollution and finally human and animal health through consumption of contaminated crops.

The physicochemical and microbiological parameters tested in all the samples show increased concentration of pollutant metals above the recommended values for corresponding parameters in the Environmental Management and Coordination (Water Quality) Regulations 2006 standards for irrigation water. Increased $\mathrm{TDS}, \mathrm{Al}, \mathrm{Cd}, \mathrm{Cr}, \mathrm{Co}, \mathrm{Cu}, \mathrm{Zn}$ and $\mathrm{Pb}$ concentrations in the treated effluent, discharge point, upstream Nairobi River, raw influent and downstream Nairobi River surpassed the recommended values for corresponding parameters in the Environmental Management and Coordination (Water Quality) Regulations, 2006 standards for irrigation. Despite undergoing treatment process, the treated effluent sample did not meet the standard for irrigation either. Total coliforms and Escherichia coli cells in all the five samples also exceeded the recommended values for corresponding parameters in the Environmental Management and Coordination (Water Quality) Regulations, 2006 microbiological quality guidelines for wastewater use in irrigation.

\section{RECOMMENDATION}

The study recommends further research targeting other parameters not covered in the study. It also recommends analysis of all types of water used for irrigation to confirm levels of compliance to the Environmental Management and Coordination (Water Quality) Regulations, 2006 standards for irrigation water and microbiological quality guidelines for wastewater use in irrigation. The raw influent despite undergoing treatment, the treated effluent was found to be contaminated with elevated levels of $\mathrm{Al}, \mathrm{Cd}, \mathrm{Cr}, \mathrm{Co}, \mathrm{Cu}, \mathrm{Zn}$ and $\mathrm{Pb}$, which could be attributed to inefficiency of the Ruai domestic wastewater and industrial wastewater treatment plant. The study therefore recommends improvement of the Plant to make it more efficient.

\section{ACKNOWLEDGEMENT}

The authors acknowledge laboratory technicians in the Directorate of Mines and Geology, and Water Resources Authority for assisting in analysis of water samples. We are equally grateful to the vegetable farmers for showing us sources of water they use for irrigation. Last but not least, we thank Daniel Bosire for his logistical support during water sampling.

\section{REFERENCES}

[1] Abbas, H., Rashed, H. \& El-Zaeaty, D. (2015). Assessment of wastewater quality for irrigation purposes. Annals of Agric. Sci., Moshtohor. 53(4): $765-$ 774.

[2] Ali, M. and Al-Qahtani, K. (2012). Assessment of some heavy metals in vegetables, cereals and fruits in Saudi Arabian markets. National institute of 
oceanography and fisheries. The Egyptian Journal of Aquatic Research. 38(1): 31-37.

[3] Bagdatlioglu, N., Nergiz, C., \& Ergonul, P. G. (2010). Heavy metal levels in leafy vegetables and some selected fruits. Journal of Consumer Protection and Food Safety. 1661-5751.

[4] Bashir, F., Kashmiri, M., Shafiq, T., \& Tariq, M. (2009). Heavy metals uptake by vegetables growing in sewage irrigated soil: relationship with heavy metal fractionation in soil, Chemical Speciation \& Bioavailability. 21(4): 199-209.

[5] Bawiec, A., Paweska, K. \& Jarsab, A. (2016). Changes in the microbial composition of municipal wastewater treated in biological processes. Journal of Ecological Engineering. 17(3): 41-46.

[6] Buechler, S., Mekala, G. \& Keraita, B. (2006). Wastewater use for urban and peri- urban agriculture. Paper first published as Chapter 9 of the Resource Centres of Urban Agriculture \& Food Security (RUAF) publication 'Cities Farming for the Future; Urban Agriculture for Green and Productive Cities' by René van Veenhuizen (ed.), RUAF Foundation, the Netherlands, IDRC, Canada and IIRR publishers, the Philippines, 2006 (460 pages).

[7] Christensen, R. (2018). One-way ANOVA. Analysis of Variance, Design, and Regression, 277-321.

[8] Codex Alimentarius Commission (FAO/WHO) (2001). Food additives and contaminants. Joint FAO/WHO Food standards program, 01/12a: 1-289.

[9] Codex Alimentarius Commission (WHO/FAO) (2001). Food additives and contamination. Joint FAO/WHO Food Standards program, p $45-48$.

[10] Drechsel, P., Scott, C. A., Raschid-Sally, L., Redwood, M. \& Bahri, A. (2010). Wastewater irrigation and health: assessing and mitigating risk in low-income countries. Colombo, Sri Lanka: International Water Management Institute (IWMI); London, UK: Earthscan; Ottawa, Canada: Internaional Development Research Centre (IDRC). 404p.

[11] Eaton, A. D. M. A. H. (2005). Standard methods for the examination of water and wastewater. 21st Edition. Centennial Ed. Printed and bound in Washington DC: American Public Health Association.

[12] Environmental Management and Coordination (Water Quality) Regulations, 2006.

[13] Gezahegn, W. W., Srinivasulu, A., Aruna1, B., Banerjee, S., Sudarshan, M., P.V. Narayana, L. P. V. \& Rao, A.D.P. (2017). Study of heavy metals accumulation in leafy vegetables of Ethiopia. IOSR Journal of Environmental Science, Toxicology and Food Technology (IOSR-JESTFT). 11 (5): 57-68.

[14] Glenda, F. (2012). Analysis of Variance and Interaction.

[15] Hussain, I., Raschid L., Hanjra, M. A., Marikar, F. \& Van der Hoek, W. (2002). Wastewater use in agriculture: review of impacts and methodological issues in valuing impacts. Colombo, Sri Lanka: International Water Management Institute (IWMI), (Working Paper 037). 2002; 55.

[16] Jeong, H., Kim, H. \& Jang, T. (2016). Irrigation water quality standards for indirect wastewater reuse in agriculture: a contribution toward sustainable wastewater reuse in South Korea. 8 (169).

[17] Jiménez, B. (2006). Irrigation in developing countries using wastewater. Special feature on groundwater management and policy. International review for environmental strategies. 6 (2): $229-250$.

[18] Kaluli, J., Githuku, C., Home, P., \& Mwangi, B. (2011). Towards a national policy on wastewater reuse in Kenya. Policy on wastewater. Journal of Agriculture, Science and Technology. 13 (1): 116-125.

[19] Karanja, N., Njenga, M., Prain, G., Kangethe, E., Kironchi, G., Githuku, C., Kinyari, P. and Mutua, G. K. (2016). Assessment of environmental and public health hazards in wastewater used for urban agriculture in Nairobi, Kenya. Tropical and Subtropical Agroecosystems, 12: (85 -97)

[20] Kenya National Bureau of Statistics (KNBS) 2019. Kenya population and housing census. Vol. I: Population by county and sub-county.
[21] Khalid, S., Shahid, M., Natasha, Bibi, I., Sarwar, T., Shah, A. H., \& Niazi, N K. (2018). A review of environmental contamination and health risk assessment of wastewater use for crop irrigation with a focus on low and high-income countries. International Journal of Environmental Research and Public Health 2018. 15 (5): 895.

[22] Kiernan, D. (2014). Natural resources biometrics.

[23] Magnusson, U. and Bergman, K. F. (Eds). (2014). Urban and peri- urban agriculture for food security in low- income countries- Challenges and knowledge gaps. SLU-Global Report 2014:4.

[24] Maheshwari, B. S. (2016). Balanced urban development: Options and strategies for liveable cities.

[25] Mbui, D., Chebet, E., Kamau, G. \& Kibet, J. (2017). The state of water quality in Nairobi River, Kenya. Asian J. Research Chem. 9(11).

[26] Naser, H., Rahman, M., Sultana, S., Quddus, M. \& Hossain, M. (2018). Heavy metal accumulation in leafy vegetables grown in industrial areas under varying levels of pollution. Bangladesh J. Agril. Res. 43(1): 39-51.

[27] Ndunda, E. N. and Mungatana, E. D. (2013). Farmers' perception and knowledge of health risks in wastewater irrigation. Open science repository natural resources and conservation.

[28] Njenga, M., Karanja, N. \& Magoiya, J. (2011). Risks associated with urban wastewater irrigation and production of traditional African vegetable (ATVs) seeds in Nairobi, Kenya. Article in Acta horticulture.

[29] Njuguna, S. M., Yan, X., Guturu, R. W., Wang, Q. \& Wang, J. (2017) Assessment of microphyte, heavy metal, and nutrient concentrations in the water of the Nairobi River, Kenya. Environ Monit Assess (2017) 189: 454

[30] Omwenga, M. (2011). Integrated system for liveable city environment: A case study of Nairobi Kenya, 47th ISOCARP Congress 2011.

[31] Percival, S. L. and Williams, D. W. (2014). Microbiology of waterborne diseases (2nd Edition). Microbiological aspects and risks. 89-117.

[32] Qadir, M., Wichelns, D., Raschid-Sally, L., McCornick, P. G., Dreschel, P., Bahri, A. \& Minhas, P. S. (2010). The challenges of wastewater irrigation in developing countries. Agricultural water management 97 (4): 561-6568.

[33] Ruma, M. M. and Sheik, A. U. (2010). Reuse of wastewater in urban farming and urban planning implications in Katsina metropolis, Nigeria. Full length research paper. African Journal of Environmental Science and Technology. 4 (1): 028-033.

[34] Ware, W. B., Ferron, J.M. \& Miller, B. M. (2013). Introductory statistics: A conceptual approach using R. Routledge.

[35] WHO (2006). Guidelines for the Safe Use of Wastewater, Excreta and Greywater - Volume 2: Wastewater use in agriculture.

\section{AUTHORS}

First Author - David K. Rono, Masinde Muliro University of Science and Technology, Department of Disaster Management and Sustainable Development, P. O. Box 190-50100 Kakamega, Kenya

Second Author - Joseph P. Gweyi-Onyango, Department of Agricultural Science and Technology, Kenyatta University, P. O. Box 43844-00100 Nairobi, Kenya

\section{Correspondence Author - darap_rono@yahoo.com}

